\title{
e-Migrinter
}

22 | 2021

Varia

\section{Young immigrants and their schooling: learning pathways and challenges}

Report of the concluding round table of the conference cycle

"Migrations and life cycle" organised by the Espace Mendès France,

Migrinter, and students of the Master in International Migration, on 25

March 2021

Lola Bultel, Bonnie Couillet, Lise Fauvre and Luna Russo

\section{Q OpenEdition}

Journals

Electronic version

URL: https://journals.openedition.org/e-migrinter/2787

DOI: 10.4000/e-migrinter.2787

ISSN: 1961-9685

Publisher

UMR 7301 - Migrinter

Electronic reference

Lola Bultel, Bonnie Couillet, Lise Fauvre and Luna Russo, "Young immigrants and their schooling: learning pathways and challenges", e-Migrinter [Online], 22 | 2021, Online since 25 November 2021, connection on 17 December 2021. URL: http://journals.openedition.org/e-migrinter/2787 ; DOI: https:// doi.org/10.4000/e-migrinter.2787

This text was automatically generated on 17 December 2021.

Tous droits réservés 


\section{Young immigrants and their schooling: learning pathways and challenges}

Report of the concluding round table of the conference cycle "Migrations and life cycle" organised by the Espace Mendès France, Migrinter, and students of the Master in International Migration, on 25 March 2021

Lola Bultel, Bonnie Couillet, Lise Fauvre and Luna Russo

\section{REFERENCES}

Round table discussion with Virginie Baby-Collin, Professor of Geography, AixMarseille University, Telemme laboratory (CNRS) and Julie Vinot, Teacher of French literature and French as a foreign/second language at the high school Pilote Innovant International (LP2i) in Jaunay-Marigny. Poitiers, 25 March 2021

Report on the round table discussion ${ }^{1}$ with Virginie Baby-Collin, Professor of Geography, AixMarseille University, Telemme laboratory (CNRS) and Julie Vinot, Professor of literature, French as a foreign language at the Lycée Pilote innovant international in Jaunay-Marigny, Poitiers, on 25 March 2021, organised and moderated by the authors of this report.

This conference was organised as a collective effort.

We would like to thank Virginie, Cécile and Julie for their time, their kindness and their precious advice.

We would like to thank the students of LP2i, Fatima Naasam, Pengyu Liang, Junior Boris Deffo Talla, Vu Duy Nguyen, Mohamed Touihar, Pouyan Khosravi, for sharing their time and their words.

Finally, a big thank you to Brenda Le Bigot, Jordan Pinel and Héloïse Morel for giving us this opportunity and for their guidance. 


\section{Introduction}

1 The round table was organised as part of a series of conferences on international migrations and the fight against discrimination organised by the Espace Mendès France and the Migrinter laboratory of the University of Poitiers. Under the supervision of Brenda Le Bigot and Jordan Pinel, geographers at the laboratory, four students from the International Migrations master's degree and members of the Migr'Avenir Association (Lola Bultel, Bonnie Couillet, Lise Fauvre, Luna Russo), took on the project. The topic of the schooling of newly arrived non-native speaker children (hereafter referred to as EANA ${ }^{2}$ ) in France was chosen for its importance and to be in line with the central theme of the 2019 conference cycle "Migrer tout au long de la vie" (Migration at all stages of life).

2 The objective of the round table was to highlight different contexts and approaches taken from a social science perspective and through the lens of professionals in the field and the pupils themselves. With this aim, the invitees, Julie Vinot and Virginie Baby-Collin, described the heterogeneous nature of the learning pathways and educational methodology that are implemented in France.

3 Julie Vinot is a teacher in charge of a UPE2A ${ }^{3}$ (a unit coordinating schooling for EANAs) at the high school ${ }^{4}$ Pilote innovant international in Jaunay-Marigny (a high school near Poitiers). Virginie Baby-Collin is a researcher and professor of Geography at the University of Aix-Marseille. She is a member of the Telemme laboratory (CNRS) and, as part of her research projects, monitors the schooling of EANAs in a UPE2A in a high school in Marseille. She is conducting this research with Cécile Exbrayat, who has been a teacher coordinator of this unit since its opening, Luna Russo (doctoral student, Telemme and Adef, AMU), and Polina Palash (post-doctoral student, Telemme, AMU). This research mainly uses qualitative methods (interviews with students and socioeducational actors and regular communication with the pupils). It is important to point out that, compared to Poitiers, the research work carried out in Marseille has provided a more in-depth knowledge of the field from a social science perspective.

\section{The schooling of newly arrived non-native speaker pupils in France}

4 The schooling of immigrant pupils has aroused growing interest in the field of social science over the last decade. This area of research, which brings together migratory and educational issues, has seen an increase due to the development of work focused on migration, but also because the number of migrant pupils enrolled in French schools has increased since the beginning of the 21st century.

5 The presence of foreign pupils in French schools is not recent. From the 1970s they were schooled in specific closed classes. Although in the 1980s, the numbers stagnated or even decreased, they have since increased: from 32,000 in 2001-2002 to almost 70,000 in 2018-19. Since circular no. 2012-141 (BOEN, 2012), immigrant pupils are referred to as EANA in France. They are characterised by two main criteria: they are non-native French speakers and they are newly arrived in France (theoretically less than a year). Since 2012, they are schooled in open facilities called UPE2A in France, which exist at 
primary and secondary levels. For this round table the focus is on EANAs enrolled in UPE2As in general high schools. With courses in French and inclusion ${ }^{5}$ in so-called ordinary classes (theoretically for one year), the EANAs - over sixteen years of age and with proof of previous schooling- are able to continue their studies in the French school system. However, these pupils, who come from often complex and difficult migratory backgrounds face many challenges: a new school with a new language of schooling, new methods of learning and new cultural codes (Armagnague et al., 2018; Guedat-Bittighoffe, 2015).

In order to be educated in France, EANAs over 16 years old must take a placement test carried out by the CASNAV which stands for the Academic Centre for the Schooling of Newly Arrived Children and Children from Itinerant and Travelling Families and the Information and Career Guidance Centres (referred to as $\mathrm{CIO}$ in France). This test assesses their French and academic level. Depending on the results, the pupil is assigned to his or her age group. Some students are assigned to a specific class such as UPE2A, others to an ordinary class without specific language support. Once the test has been carried out, the assignment is not immediate: delays can be long (especially at the high school) and the number of places is limited in relation to the number of EANAs present in the catchment area.

7 Thus, the schooling of EANAs raises many issues: teacher training, pedagogical practices, orientation, the pupils' educational experiences; all these points were addressed by Julie Vinot and Virginie Baby-Collin. Although some work has already been carried out, there is a lack of data on their orientation, learning pathways and level of success in school (Caille \& Vallet, 1996; Schiff, 2002; Felouzis \& FouquetChauprade, 2016; Armagnague et al., 2018a, b, 2019).

\section{Focus on two schemes for EANAs in Poitiers and Marseille}

\section{Context}

The two speakers highlighted the fact that, despite a migratory presence in both Marseille and Poitiers, the migratory and educational contexts are distinct.

Virginie Baby-Collin presented the context in Marseille. Over the last twenty years, the number of EANAs has increased significantly in the academy and many new schemes have been initiated. These are mainly concentrated in Marseille - ranked 20th of the 100 poorest municipalities in France (Audren et al., 2018) - where 80\% of EANAs attend school and are mainly in the priority education networks known as REP and REP $+{ }^{6}$. In this academy, the vast majority of the UPE2As are in vocational high schools ${ }^{7}$. The one studied in the research presented by Virginie Baby-Collin is the only one in the Académie to be a UPE2A in a general high school, for which the pupils must prove a previous level of schooling equivalent to at least the end of $3^{\text {rd }}$ class (equivalent of year 10 in UK).

This UPE2A of the high school Saint-Charles, situated in a multicultural neighbourhood, was created in 2014. The high school offers courses in rare language such as Russian and Armenian as well as international sections and bilingual classes. Since 2014, the same teacher, Cécile Exbrayat, has coordinated the unit. About 130 students 
(predominantly boys) have integrated this UPE2A. They come from a wide range of countries (more than thirty), although two dominate: Algeria and Armenia.

11 Our second speaker, Julie Vinot, introduced us to LP2i, the school where she is the UPE2A coordinating teacher. LP2i is a general and technological high school ${ }^{8}$ which hosts one of only two UPE2As ${ }^{9}$ at high school level in the academy of Poitiers. The Vienne is one of the six départements with the lowest number of EANA pupils enrolled (less than 20\%) in UPE2A facilities (Ministry of National Education, Youth and Sport, 2020). Lp2i is a high school that has been operating since its creation in the 1980 s around a so-called innovative pedagogy, based on project-based teaching, digital innovation, subject decompartmentalisation, student mentoring and an international approach. Pupils and adults regularly rethink the scope and direction of the initiative which has constantly changed and evolved over the years. The inclusion of EANAs since 2007 is one of the main axes of this reflection.

12 Although the LP2i school does not have the UPE2A label, it functions as such. In both establishments, the EANAs take between 10 and 16 hours of French weekly as a second language ${ }^{10}$ (called FLS in French), as well as FLS co-teaching (history-geography, science, philosophy, physics-chemistry for example) and hours in their normal classes (mathematics, English and PE at Saint-Charles; PE, Languages, mathematics, Biology, physics-chemistry, history-geography at Jaunay-Marigny ${ }^{11}$. Thus, EANAs spend many hours together and others with native French-speaking students.

13 At LP2i, three teachers (French teachers trained to teach French as a second language and with additional qualifications) accompany these students during their $2^{\text {nd }}$ class (equivalent of year 11 in the UK) in the unit and then throughout their schooling in this high school, that is to say their year of Première and Terminale. The system is not destabilised despite its changing nature: from one year to the next, the UPE2A changes according to the new pupils, the decisions of the teaching team and also the number of hours allocated. In Marseille, pupils theoretically spend one year in the unit (about 20\% stay for a second year). And there is only one teacher dedicated to the scheme. As a result, support after leaving the unit is provided on a more individualised and informal basis by Cécile Exbrayat. One of Cécile Exbrayat's challenges is to monitor the coordination of the scheme so that, the following year, the progress of the pupils in French is taken into account in their assessments and school orientation. Their lack of fluency in French should not be understood as a failure at school. Thus, the coordinating teacher must be in constant communication with the other teachers and educational actors in the high school (and even in other establishments) to ensure that their progress as EANAs is taken into account, even after they have left the scheme.

\section{The challenges at school}

14 On the occasion of this conference, some students from the UPE2A of LP2i agreed to share their experiences. Due to COVID restrictions, they were unable to participate in the conference, so they intervened via a podcast ${ }^{12}$ which was presented at the round table.

First of all, the young students identify language as the main barrier not only in following the courses but also in their socialisation with native French-speaking students. However, the core of the scheme is to prevent this phenomenon. The coordinating teachers consider that a language implies a vision of the world, a 
collective and personal history, and an emotional force for the student. The role of the teachers is therefore to form a bridge between French as the language spoken at school and their mother tongue(s). EANAs have a rich and diverse linguistic repertoire (Chnane Davin, 2020): they generally master at least two languages. With this in mind, the two teachers put forward two techniques in their pedagogical approaches. On the one hand, they ensure that the teaching in UPE2A values the pupils' mother tongues and the stories they carry. For example, the reading and translation of a text from a mother tongue into French can leave space for a plurilingual debate on the interpretation of this text. French is thus taught in all its dimensions and in relation to other languages. These elements ensure that French is not imposed as a tool for 'acculturation'. On the other hand, the teachers use many types of materials and/or activities to motivate language learning. At Lp2i, activities are set up with pupils from so-called ordinary classes, thanks in particular to artistic collectives such as $\mathrm{ACTE}^{13}$; in Saint-Charles, Cécile Exbrayat works with the Association for the Promotion of Literary Translation $^{14}$, with which pupils translate a text from French into their mother tongue(s) or vice versa. The aim is for the pupils to discuss their interpretation of the translation.

16 A second issue raised was the isolation of the UPE2A in schools. As school is a traditional hub of socialisation for all young people, it is, even more, the case for allophone pupils who, having recently arrived, have few points of reference (BabyCollin et al., to be published in 2021). The LP2i students told us of their real difficulties building relationships within the school, despite attending classes with native Frenchspeaking students. This isolation affects the unit in general. In the texts (BOEN, 2012), the education of EANAs must concern all socio-educational actors in the schools. However, the teachers in the systems very often find themselves having to manage the pupils alone (Rigoni, 2020). They are the ones who take charge of building an inclusion policy within the schools. At LP2i, the school's staff are united around the common objective of building an international outlook, which means that the work of the UPE2A teachers is not isolated and that they can find support and collective consultation. At Saint-Charles high school, Cécile Exbrayat does not have as much support in the school and struggles with other teachers to reduce the isolation. Finally, the effectiveness of inclusive education relies heavily on budgets, materials and staff commitment, which vary from school to school.

17 A third issue raised was the commitment of teachers to go beyond their purely academic functions in relation to this group. As the first point of contact for allophone pupils and their families, teacher-coordinators have an overall view of young people and their living conditions outside school. Without this being the only cause of precariousness, the migratory paths and administrative situation of these young people have an impact on their living conditions and consequently on their school career (Armagnague et al., 2018).

18 Their migratory paths are heterogeneous, they come from different countries, from different socio-economic backgrounds; some have stayed in refugee camps, others have arrived with their families or alone; some were in school before migrating, others were not. Julie Vinot shared these difficulties. For example, children and their families are frequently concerned about the regularisation of their legal status and the threat of an Obligation to Leave the Territory (OQTF). Like Cécile Exbrayat, they face very technical issues such as the need to request an interpreter to communicate with the family, the 
consideration of the student's administrative situation, which involves appointments at the Prefecture or the French Office for Immigration and Integration (OFII). In addition, their residential situation may also be unstable. Some are housed in social hostels or find themselves homeless if they are not taken care of in specific structures (Bouillon et al., 2019). These situations can disrupt their psychological well-being, cause them to miss classes and be late. This raises issues of teacher training and emotional engagement.

This observation leads to questions about the informal or 'non-contractual' responsibilities of the teachers who are faced with situations that go beyond the strictly educational role (Mendonça Dias \& Rigoni, 2019). Involvement in associations in parallel with the status of teacher is one of the options chosen to cope with this. Julie Vinot points out that this "charity work starts to infringe on their personal life". Faced with the failings of the State, it is necessary to turn towards charities and noninstitutional actors. The Saint-Charles high school has a link with Réseau Éducation Sans Frontières (RESF) ${ }^{15}$. Together, they organise fundraising events at the school, in order to help pay for young students to be put up in a hotel. This leads to teachers investing both time and emotion (Azaoui, 2020).

In the last part of the presentation, the speakers highlighted issues in relation to the continuation of schooling. They recalled that the UPE2A is intended for pupils to follow an ordinary schooling, and they must therefore choose a path for the rest of their schooling. Several choices are possible: integrating general, technological or vocational studies. Educational and career guidance is given from the beginning of the year and is refined throughout the year. The teachers refuse to accept a schooling path by default and work on one chosen by the pupil.

Julie Vinot and Virginie Baby-Collin questioned the relation between the fact of being newly arrived and the construction of educational and career guidance. Several elements come into play, such as migration policies and regularisation criteria, the premigratory situation, the role of the School in reproducing systemic discrimination, and accommodation conditions. One of the particular elements to be taken into account is their linguistic abilities. As we have seen, the approach of educational coordinators is to stress the added value of the multilingualism of EANAs, which should be an asset in terms of educational and career guidance. However, it is not so simple: it is difficult to ensure that their mother tongue is a possible second language for the Baccalauréat exams. So, some young people have to learn Spanish, for example - in addition to the French and English they are already learning - even though they have mastered other languages. In this context, teachers are struggling to give EANAs the opportunity to take courses at the Centre national d'enseignement à distance (CNED) ${ }^{16}$. Far from being simple, enrolment in the CNED depends not only on the willingness and resources of the school management but also on the choice of languages in the CNED.

\section{Conclusion}

The schooling of newly arrived non-native speakers' children is challenging. While school is a main space of socialisation, the arrangements put in place to accommodate these pupils raise the question of school inclusion. Taking into account the words of these young people has made it possible to capture the obstacles they sometimes face in their schools. Language is one of the first barriers, along with isolation and the 
difficulty for them to define their study paths. The testimonies of Virginie Baby-Collin and Julie Vinot prove that the commitment of teachers plays an essential role in the schooling of these students, as does the school's willingness to fully integrate them.

More generally, the conference highlighted the importance of networking between various "support structures" (school, associations, legal, accommodation facilities, families) and researchers in the social sciences.

\section{BIBLIOGRAPHY}

Armagnague-Roucher, Maitena ; Rigoni, Isabelle ; Cossée, Claire ; Mendonça Dias, Catherine ; Tersigni, Simona (2018) Rapport de recherche EVASCOL. Étude sur la scolarisation des élèves allophones nouvellement arrivés (EANA) et des enfants issus de familles itinérantes et de voyageurs (EFIV). Défenseur des Droits. INSHEA - Institut national supérieur de formation et de recherche pour l'éducation des jeunes handicapés et les enseignements adaptés. https://halshs.archivesouvertes.fr/halshs-01992643/document

Armagnague-Roucher, Maitena ; Rigoni, Isabelle ; Valette, Marie-Fraçoise dir. (2018) Dossier : École et migration, Revue européenne des migrations internationales, vol. $34, \mathrm{n}^{\circ} 4,248 \mathrm{p}$. https:// doi.org/10.4000/remi.11498

Armagnague-Roucher, Maitena ; Rigoni, Isabelle ; Tersigni, Simona (2019) Dossier : La scolarisation des élèves migrants en France. Migrations Société, vol. 41, n¹76. 196 p. https://doiorg.ressources.un

Audren, Gwenaelle ; Baby-Collin, Virginie ; Valcin, Marguerite (2018) L'école, une ressource pour les populations migrantes. Regards croisés de l'institution et des parents d'élèves dans le centreville de Marseille, Revue européenne des migrations internationales, vol. 4, nº 4, pp. 93- 118. https:// doi.org/10.4000/remi.11751

Azaoui, Brahim (2020) Enseigner auprès d'élèves en situation de grande précarité : du désir didactique à la souffrance ressentie. In Mendonça Dias, Catherine ; Azaoui, Brahim ; ChnaneDavin, Fatima. (dir), Allophonie. Inclusion et langues des enfants migrants à l'école, pp. 107-122, Lambert-Lucas.

Baby-Collin, Virginie ; Exbrayat, Cécile ; Russo, Luna (à paraitre 2021) Trajectoires scolaires et fabrique de l'orientation scolaire de lycéens migrants allophones. Le cas d'un lycée de Marseille, Jeunes et mineurs en mobilité, nํ6

Baby-Collin, Virginie ; Exbrayat, Cécile ; Palash, Polina ; Russo Luna (à paraitre, 2021) Covid 19, confinement et élèves migrants. Le cas de lycéens marseillais. In Baby-Collin, Virginie \& Souiah, Farida (dir). Enfances et jeunesses en migration, Le Cavalier bleu-MMSH

Bouillon, Florence ; Deboulet, Agnès ; Dietrich-Ragon, Pascale ; Fijalkow, Yankel (2019) Vulnérabilités résidentielles, Bibliothèque des territoires. De l'Aube. 263 p.

Bulletin Officiel de l'Éducation Nationale (2012) Organisation de la scolarité des EANA, Circulaire no2012-141. 
Chnane-Davin, Fatima (2020) De quoi faut-il tenir compte lorsqu'on enseigne le français langue étrangère et seconde ?, In Defays, Jean-Marc, Le FLE en questions: Enseigner le français langue étrangère et seconde. pp. 149-198. https://doi.org/10.3917/mard.defay.2020.01.0149

Felouzis, Georges \& Fouquet-Chauprade, Barbara (2016) Les descendants d'immigrés à l'école, Revue française de pédagogie, vol. 2, n², pp. 5-10. https://doi.org/10.4000/rfp.4736

Guedat-Bittighoffe, Delphine (2015) La scolarisation des élèves allophones au collège : étude comparative des modalités d'organisation de quatre dispositifs d'accueil et des effets potentiels sur l'apprentissage du français, Les Sciences de l'éducation - Pour l’Ère nouvelle, vol. 3, n³, pp. 83107. https://doi.org/10.3917/lsdle.483.0083

Mendonça Dias, Catherine \& Rigoni, Isabelle (2019) La demande d'asile : impacts sur la scolarisation de l'enfant et rôles de l'enseignant. Migrations Société, vol. 176, n², 49-63. doi: 10.3917/migra.176.0049.

Ministère de l'Éducation nationale de la Jeunesse et des Sports (2020) Note d'information 20.39, 67 909 élèves allophones nouvellement arrivés en 2018-2019: neuf sur dix bénéficient d'un soutien linguistique ou d'une scolarité dans un dispositif spécifique. Fabienne Rosenwald, Laurence Brun, DEPP-B1. Consulté le 15 octobre 2021 sur https://archives-statistiques-depp.education.gouv.fr/Default/ digital-viewer/c-47074

Ministère de l'Éducation Nationale et de la Jeunesse et des Sports, Éduscol (2021) Ressources pour l'accueil et la scolarisation des élèves allophones nouvellement arrivés (EANA). Consulté le 15 mai 2021 sur https://eduscol.education.fr/1191/ressources-pour-l- accueil-et-la-scolarisation-des-elevesallophones-nouvellement-arrives-eana

Rigoni, Isabelle (2020) Enseigner aux allophones. Représentations du métier et pratiques de terrain. In Mendonça Dias, Catherine ; Azaoui, Brahim ; Chnane-Davin, Fatima. (dir), Allophonie. Inclusion et langues des enfants migrants à l'école, pp. 91-106, Lambert-Lucas.

Schiff, Claire (2002) Les jeunes primo-arrivants : un rapport à la société distinct de celui des minorités ethniques, VEI-enjeux, nำ131, pp. 222-231

UNESCO (2009) Principes directeurs pour l'inclusion dans l'éducation. 38 p. https:// unesdoc.unesco.org/ark:/48223/pf0000177849_fre

Vallet, Louis-André \& Caille, Jean-Paul (1996) Les élèves étrangers ou issus de l'immigration dans l'école et le collège français, Les dossiers d'éducation et formation, $\mathrm{n}^{\circ} 67,153 \mathrm{p}$.

\section{Resource page}

Association pour la promotion de la traduction littéraire : https://www.atlas-citl.org/ association/

Baby-Collin, Virginie ; Vinot, Julie - Espace Mendès France (2021, 25 mars) Les jeunes migrants et l'école : parcours et enjeux de scolarisation. (vidéo). YouTube. URL: https://www.youtube.com/ watch? $\mathrm{v}=\mathrm{lMcn} 2 \mathrm{AKnmKM} \& \mathrm{t}=2138 \mathrm{~s}$

Centre national d'enseignement à distance : https://www.cned.fr/

Collectif ACTE : https://www.collectif-acte.fr/a_propos

Migr'Avenir (2020) Les jeunes migrant·es et l'École : la parole des jeunes concernées (stream). Soundcloud. URL : https://soundcloud.com/user-112767485/les-jeunes-migrants-et-lecoleparcours-et-enjeux-de-scolarisation-la-parole-des-jeunes-concernees 


\section{NOTES}

1. Available on YouTube: https://www.youtube.com/watch?v=lMcn2AKnmKM\&t=2138s

2. French acronym for Élèves allophones nouvellement arrivé.es.

3. French acronym for Unité pédagogique pour élèves allophones arrivant·es.

4. In France, high school is in two stages: collège (secondary education from the ages of 11 to 15) and lycées which is a three-year course for children between the ages of 15 and 18. Pupils are prepared for the baccalauréat. In this text by "high school” we mean Lycée.

5. Inclusion, defined as "a process of taking into account the diversity of students' needs and responding to them through increasing participation in learning" (UNESCO, 2009, p. 14), appeared in 2005 in the context of the education of students with disabilities. Today, it encompasses all students with special educational needs (Ministry of National Education, Youth and Sports, 2021), including EANAs, and aims to improve equality of opportunity.

6. Les réseaux d'éducation prioritaire, REP are priority education network.

7. Unlike the UPE2A in general high school, the UPE2A in vocational high school are not intended for inclusion and are closed classes that act as a platform for initial schooling in France.

8. The high school has become a general and technological school since September 2021 with the opening of a Science and Technology of Management and Administration (STMG) course.

9. While the scheme functions, as it stands, exactly like a UPE2A, it does not have the official name of one. The team prefers to call it a "unit for FLS- inclusion of EANA".

10. French as a second language and as a language of schooling refers to French taught as a language of institution and schooling. Students learn French not only for their daily life (as French as foreign language) but also for study.

11. The timetable of EANAs enrolled in UPE2A evolves. That is to say that as the year progresses, the students can integrate more regular class courses such as physics and chemistry. All this is changeable and needs to be rediscussed each year depending on the timetable of the high school, for example.

12. Available on Souncloud: https://soundcloud.com/user-112767485/les-jeunes-migrants-etlecole-parcours-et-enjeux-de-scolarisation-la-parole-des-jeunes-concernees

13. Collectif ACTE. https://www.collectif-acte.fr/a_propos

14. Association for the Promotion of Literary Translation. https://www.atlas-citl.org/ association/

15. Education Without Borders Network.

16. The National Centre of Distance Learning.

\section{AUTHORS}

\section{LOLA BULTEL}

Research engineer at the Migrinter laboratory in the framework of the "Positive Migration" project led by the Observatory of Migration of Minors, lola.bultel@laposte.net

\section{BONNIE COUILLET}

Student in Master 2 International Migrations at the University of Poitiers, couilletb@gmail.com 


\section{LISE FAUVRE}

Student in Master 2 International Migrations at the University of Poitiers, lise.fauvre@outlook.fr LUNA RUSSO

Doctoral student, Aix-Marseille University, Telemme and Adef laboratories, AMPIRIC pilot centre, luna.RUSSO@univ-amu.fr 